\title{
Biological system for improving the availability of Tilemsi phosphate rock for wheat (Triticum aestivum $\mathbf{L}$.) cultivated in Mali*
}

\author{
A.H. Babana ${ }^{1,2}$ and H. Antoun ${ }^{2, *}$ \\ ${ }^{1}$ Faculté des Sciences et Techniques, Université du Mali, 3206 Bamako, Mali; ${ }^{2}$ Département des Sols et de \\ Génie Agroalimentaire, Faculté des Sciences de l'Agriculture et de l'Alimentation, Pavillon Charles-Eugène Marc- \\ hand, Université Laval, Québec Qc, Canada G1K 7P4; *Author for correspondence (e-mail: \\ antoun@rsvs.ulaval.ca; phone: +1-418-656-2131, ext. 3650; fax: +1-418-656-7176)
}

Received 1 September 2004; accepted in revised form 30 December 2004

Key words: Aspergillus awamori, Mycorrhiza helper bacteria, Penicillium chrysogenum, Phosphate solubilizing microorganisms, Plant growth promotion, Pseudomonas sp.

\begin{abstract}
The Tilemsi phosphate rock (TPR) of Mali is a good and cheaper alternative to imported phosphate fertilizers. Many soil microorganisms can also mobilize sparingly soluble inorganic phosphates, and several have a good potential to improve plant growth. With the aim of improving the response of wheat cultivated in Mali to fertilization with TPR, in this work we describe the isolation and selection from four different Malian soils of TPR-solubilizing microorganisms (TSM) with high P-mobilization activities. When the rhizosphere of three wheat cultivars (Alkama Beri, Hindi Tossom and Tetra) was used to isolate TSM, only bacterial isolates were selected. TPR-solubilizing fungi were only obtained by soil enrichment in liquid medium containing TPR as sole $\mathrm{P}$ source. In the rhizosphere a significant correlation was observed between the total microbial population and the number of microorganisms solubilizing TPR. No such correlation was observed in the rhizoplane. Initially 44 bacteria and 18 fungi were selected, but after 10 subcultures on agar plates and a liquid medium, only 6 bacteria and 2 fungi retained their high P solubilizing trait. A field inoculation trial was established during the growing season 2000-2001 in Koygour. Wheat cv. Tetra was inoculated with the 8 selected TSM (6 bacteria and 2 fungi) and fertilized with $30 \mathrm{~kg} \mathrm{ha}^{-1} \mathrm{P}$ added as TPR or diammonium phosphate (DAP). The growth parameters measured were plant height at 30 and 60 days, the number of leaves per main stem at 60 days, and root and shoot dry matter yields 60 days after planting. Root colonization by indigenous arbuscular mycorrhizas (AM) was also measured in 45-day-old plants. Significant interactions were observed between TSM inoculation and P-fertilization for root colonization with AM, plant height at 30 days and root dry matter yield. The bacterial isolate Pseudomonas sp. BR2, which appeared to be a mycorrhiza helper bacterium, significantly enhanced wheat seedling emergence very early ( 5 days after planting) under field condition, and caused $128 \%$ increase in root dry matter yield. The two TPR-solubilizing fungal isolates Aspergillus awamori Nakazawa $\mathrm{C} 1$ and Penicillium chrysogenum Thom $\mathrm{C} 13$ also caused respectively 60 and $44 \%$ increases in root dry matter yields. The choice of the TSM BR2, C1 and C13 for further field trials is discussed.
\end{abstract}

\footnotetext{
*This article was previously published in Nutrient Cycling in Agroecosystems Volume 72/2 pages 147-157. The online version of the original article can be found at http://dx.doi.org/10.1007/s10705-005-0241-7
} 


\section{Introduction}

Phosphorus (P) deficiency is a major constraint to crop production in Mali and other countries in West Africa. This is due to immobilization carried out by microorganisms in $\mathrm{P}$ deficient soils and to the precipitation and fixation as insoluble complex minerals resulting from the binding of soluble $\mathrm{P}$ to aluminum and iron in acid soil or calcium in alkaline soils, depriving plants of up to $80 \%$ of soluble P added to soil (Goldstein 1986). This has forced farmers to apply 3-4 times the required amounts of $\mathrm{P}$ to crop plants, causing a substantial increase in production costs.

In Mali, imported $\mathrm{P}$ fertilizers are expensive, and the local Tilemsi phosphate rock (TPR) deposits supply the farmers with a cheaper alternative (Bationo et al. 1997). Many soil microorganisms, including bacteria and fungi, are able to mobilize sparingly soluble inorganic and organic phosphates, and they have an enormous potential in providing soil phosphates for plant growth (Richardson 2001; Gyaneshwar et al. 2002). We have recently shown that by inoculating wheat seeds with TPR-solubilizing microorganisms (TSM) in combination with a commercial isolate of the arbuscular mycorrhizal (AM) fungus Glomus intraradices, under field conditions in Mali it is possible to obtain wheat grain yields comparable to those produced by the expensive diammonium phosphate (DAP) fertilizer (Babana and Antoun 2005). In the present work we describe how the efficient TSM were obtained from Malian soils and selected for their potential use as plant growth promoting microorganisms for wheat cultivated in Mali.

\section{Material and methods}

\section{Soil samples}

Table 1 shows some physical and chemical characteristics of the $0-15 \mathrm{~cm}$ soils used to isolate the
TSM. Soils S, S1 and S2 are composite samples taken at three different sites near the phosphate mine situated northeast of Bourem in the Tilemsi Valley $\left(16^{\circ} 8^{\prime} \mathrm{N}, 1^{\circ} 6^{\prime} \mathrm{W}\right)$. Soil S3 is a composite sample taken in a field cultivated with wheat in Koygour near Diré in the Timbuktu region $\left(16^{\circ} 3^{\prime}\right.$ $\left.\mathrm{N}, 3^{\circ} 0^{\prime} \mathrm{W}\right)$.

\section{Enumeration and isolation of TPR-solubilizing microorganisms}

Microorganisms were isolated from the rhizoplane and rhizosphere of one-month-old wheat plants (cv. Alkama beri, Hindi Tosson and Tetra), according to the method described by Scher et al. (1984) modified as follows. Glass test tubes $(25 \times 200 \mathrm{~mm})$ were filled with sterile sand to a depth of $6 \mathrm{~cm}(35 \mathrm{~g})$. Autoclaved distilled water $(5 \mathrm{ml})$ was added to each tube and the sand was overlaid with $2 \mathrm{~cm}(6 \mathrm{~g})$ of tested soil adjusted to $15 \%$ moisture. Wheat seeds were surface sterilized by soaking $1 \mathrm{~min}$ in $70 \%$ ethanol, $15 \mathrm{~min}$ in $6 \%$ sodium hypochlorite, followed by 10 times rinsing in sterile distilled water. One surface sterilized seed was added per tube and covered with another $2 \mathrm{~cm}$ $(6 \mathrm{~g})$ of soil. Tubes were sealed with parafilm and incubated in a growth chamber $\left(28^{\circ} \mathrm{C}, 4000 \mathrm{lux}\right)$ for 4 weeks without added water. Plants were carefully removed from the tubes and all root segments in the sand were collected, weighed, and mixed gently in $9 \mathrm{ml}$ of saline buffer $(0.85 \% \mathrm{NaCl})$ and ten-fold serial dilutions were prepared to determine rhizosphere populations. The roots in the first dilution bottles were then washed with sterile buffer, and the soil was collected on a filter paper, and dried at $70{ }^{\circ} \mathrm{C}$ for $24-48$ h to determine the rhizosphere soil dry weight. Washed roots were re-suspended in $90 \mathrm{ml}$ of saline buffer, and shaken vigorously on a reciprocal shaker for $20 \mathrm{~min}$, and serial dilutions were performed to measure microbial populations in the rhizoplane. To

Table 1. Some characteristics of the soils used to isolate the Tilemsi phosphate rock-solubilizing microorganisms.

\begin{tabular}{|c|c|c|c|c|c|c|c|c|c|}
\hline \multirow[t]{2}{*}{ Soil sample } & \multirow[t]{2}{*}{ Sampling site } & \multirow[t]{2}{*}{ Soil texture } & \multirow[t]{2}{*}{$\mathrm{PH}\left(0.01 \mathrm{M} \mathrm{CaCl}_{2}\right)$} & \multirow[t]{2}{*}{ Organic matter $(\%)$} & \multicolumn{5}{|c|}{ Available elements $\left(\mathrm{kg} \mathrm{ha}^{-1}\right)$} \\
\hline & & & & & $\mathrm{P}$ & $\mathrm{K}$ & $\mathrm{Ca}$ & $\mathrm{Mg}$ & $\mathrm{Fe}$ \\
\hline S & Tilemsi & Sandy clay loam & 5.84 & 0.16 & 991 & 108 & 6670 & 528 & 159 \\
\hline S1 & Tilemsi & Sandy clay loam & 5.89 & 0.10 & 918 & 115 & 4250 & 561 & 152 \\
\hline $\mathrm{S} 2$ & Tilemsi & Sandy loam & 5.91 & 0.08 & 922 & 93.2 & 4149 & 502 & 153 \\
\hline $\mathrm{S} 3$ & Koygour & Silty clay loam & 6.37 & 0.17 & 6.27 & 240 & 803 & 217 & 43 \\
\hline
\end{tabular}


enumerate total microorganisms in the rhizoplane or the rhizosphere of wheat, $0.1 \mathrm{ml}$ of each dilution was spread on $1 / 10$ strength TSA (Tryptic soy broth, Difco, $3 \mathrm{~g}^{-1}$ ) medium. TSM were enumerated on the National Botanical Research Institute's Phosphate growth medium (NBRIP; Nautiyal 1999), containing per litre of distilled water: glucose, $10 \mathrm{~g} ; \mathrm{MgCl}_{2} \cdot 6 \mathrm{H}_{2} \mathrm{O}, 5 \mathrm{~g} ; \mathrm{MgSO}_{4}$. 7- $\mathrm{H}_{2} \mathrm{O}, 0.25 \mathrm{~g} ; \mathrm{KCl}, 0.2 \mathrm{~g}$ and $(\mathrm{NH} 4)_{2} \mathrm{SO} 4,0.1 \mathrm{~g}$; agar, $15 \mathrm{~g}$ and the $\mathrm{pH}$ was adjusted to 7.0. Before use, TPR was thoroughly washed with Mehlich 3 extractant solution (Mehlich 1984), and several times with hot distilled water to remove any trace of available $\mathrm{P}$, then was autoclaved and added to the sterile culture media as sole source of $\mathrm{P}$ at a concentration of $5 \mathrm{~g} \mathrm{~L}^{-1}$ (TPR-NBRIP medium).

TSM were isolated from the TPR-NBRIP plates used for enumeration. TSM were also directly isolated from soil by the following enrichment procedure. Two grams of soil were added to Erlenmeyer flasks containing $50 \mathrm{ml}$ of liquid TPRNBRIP medium. The flasks were incubated on a rotary shaker $(150 \mathrm{rpm})$ in the dark at $28^{\circ} \mathrm{C}$ for 7 days. After serial dilution in saline buffer, bacteria were isolated on TPR-NBRIP medium supplemented with $50 \mu \mathrm{g} \mathrm{ml}^{-1}$ of cycloheximide to inhibit fungal growth, and fungi were isolated on the same medium supplemented with $150 \mu \mathrm{g} \mathrm{ml}^{-1}$ streptomycin to inhibit bacterial growth and $50 \mu \mathrm{g} \mathrm{ml}^{-1}$ of Rose Bengal dye to slow down fungal radial growth. The colonies surrounded by clear zones were picked and purified by serial streaking on TPR-NBRIP agar plates incubated in the dark at $28{ }^{\circ} \mathrm{C}$. TPR-solubilizing activity of the isolates was measured in agar cultures as described by Chabot et al. (1993). After screening of a large number of isolates, 6 bacteria and 2 fungi were selected for their high solubilization activity, and were used in field inoculation trials.

In order to determine if the selected microorganisms can be used in a mixed inoculum, antagonism between bacteria and fungi was measured as previously described by Gagné et al. (1985). The nutrient broth yeast extract (NBY) culture medium used contained per liter of distilled water: Difco nutrient broth, $8 \mathrm{~g}$; Difco yeast extract, $2 \mathrm{~g}$; glucose, $10 \mathrm{~g} ; \mathrm{K}_{2} \mathrm{HPO}_{4}, 2 \mathrm{~g} ; \mathrm{KH}_{2} \mathrm{PO}_{4}, 0.5 \mathrm{~g}$, $\mathrm{MgSO}_{4} \cdot 7 \mathrm{H}_{2} \mathrm{O}, 0.2 \mathrm{~g}$, agar, $20 \mathrm{~g} ; \mathrm{pH}$ adjusted to 7.0. An $8 \mathrm{~mm}$ agar plug was taken from the edge of an actively growing fungal colony and placed in the center of an NBY plate. Each plate was also inoculated equidistantly from the center with four bacterial isolates. Control plates were not inoculated with bacteria. Plates were incubated at $28{ }^{\circ} \mathrm{C}$ and observed daily for any sign of fungal growth inhibition, until the fungal growth in the control plates reached the points of bacterial inoculation. Antagonism between bacteria was evaluated by cross streaking two different bacterial isolates on the surface of NBY plates. Plates were also incubated in the dark at $28{ }^{\circ} \mathrm{C}$ and observed daily for 7 days for any sign of bacterial growth inhibition. Production by the selected microorganisms of HCN (Bakker and Schippers 1987), siderophores (Milagres et al. 1999) and indoleacetic acid (Bric et al. 1991) was also measured. HCN, siderophores and indoleacetic acid production are in vitro characteristics frequently associated with the plant growth promotion potential of some soil microorganisms.

\section{Phosphate rock}

The TPR deposits contain between 23 and $32 \%$ of $\mathrm{P}_{2} \mathrm{O}_{5}$ and their solubility in neutral ammonium citrate is $4.2 \%$ (Bationo et al. 1997). The fine TPR powder used had the following composition (in $\mathrm{mg} \mathrm{g}^{-1}$ ): P, 150; Ca, 329; Al, 20; F, 29. The extractability of $\mathrm{P}$ from TPR determined according to Bolland and Gilkes (1997) was $16.2 \mathrm{mg} \mathrm{g}^{-1}$ in $2 \%$ citric acid and $73.4 \mathrm{mg} \mathrm{g}^{-1}$ in $2 \%$ formic acid.

\section{Wheat cultivars}

Three wheat (Triticum aestivum L.) cultivars were used: Tetra from Mali, 90 to 100 days cycle, adapted to the irrigated zones; Alkama Béri from Morocco, 90 to 100 days cycle, photoperiod sensitive; and Hindi Tosson from Egypt, 120 days cycle, photoperiod sensitive. Wheat seeds were obtained from the collection of the IER (Institut d'économie rurale) in Bamako, Mali.

\section{Wheat emergence assay}

The method was as described by De Freitas and Germida (1990). Six bacterial strains (BR2, BR8, BR10, B3, B22 and B27) and two fungal isolates 
(C1 and $\mathrm{C} 13$ ) were selected for their superior TPRsolubilizing activity. Seeds of the cultivar Tetra were inoculated as follows. Bacteria and fungi were grown in the dark for $48 \mathrm{~h}$ on TSA plates at $28^{\circ} \mathrm{C}$ and cells were suspended in $20 \mathrm{ml}$ sterile tap water. One-hundred wheat seeds were added to each bacterial suspension and agitated on a rotary shaker $(110 \mathrm{rpm})$ for $2 \mathrm{~h}$ at $10{ }^{\circ} \mathrm{C}$. At sowing each seed contained approximately $10^{5}$ bacterial cells or $10^{3}$ fungal cells. Ten inoculated seeds were planted at $20 \mathrm{~cm}$ spacings on a $2 \mathrm{~m}$ long row. The control was wheat inoculated with an autoclaved isolate (BR2). Seeds were planted at a depth of $2 \mathrm{~cm}$ in the Koygour soil (soil S3). All treatments were repeated 10 times. Seedling emergence was evaluated 5, 10, 15 and 20 days after planting.

\section{Field experiments}

Experimental plots were established in Koygour (Diré $16^{\circ} 3^{\prime} \mathrm{N}, 3^{\circ} 0^{\prime} \mathrm{W}$ ) during the 2000-2001 cropping season. A split-split plot design was used, and the main plots were phosphate fertilization with TPR or DAP applied at $30 \mathrm{~kg} \mathrm{P} \mathrm{ha}{ }^{-1}$, with a non-fertilized control, arranged in randomized complete blocks. The additional $\mathrm{N}$ added with the DAP was calculated and compensated for in all other treatments. Sub-plots were inoculated with TSM (BR2, BR8, BR10, B3, B22, B27, C1 and $\mathrm{C} 13$ ) with an uninoculated control. The main plots ( $\mathrm{P}$ fertilization) were $8 \mathrm{~m}$ wide and $31 \mathrm{~m}$ long, divided in nine subplots (TSM) $2 \mathrm{~m}$ wide and $2.5 \mathrm{~m}$ long separated by a $1 \mathrm{~m}$ wide buffer zone. Sub-subplots contained 4 rows $50 \mathrm{~cm}$ apart. Two seeds of wheat (Triticum aestivum L.) cv. Tetra were planted in each row every $20 \mathrm{~cm}$. Only the 2 central rows received seeds inoculated with TSM. All treatments were replicated 4 times. Seeds were surface sterilized and inoculated with a $1 \%$ carboxymethylcellulose solution containing the microorganisms, as previously described (Chabot et al. 1996). Planting was done on December 4, 2000. After emergence, plants were thinned to one every $20 \mathrm{~cm}$ of row. Nitrogen was applied as $50 \mathrm{~kg} \mathrm{~N}^{-1}$ urea, 2 and 7 weeks after planting which corresponded to stage 2 and stage 5 of Feekes scale (Large 1954), and a final application of $120 \mathrm{~kg} \mathrm{~N} \mathrm{ha}^{-1}$ urea at stage 10.1 (11 weeks). All plots received $80 \mathrm{~kg} \mathrm{~K} \mathrm{ha}^{-1}$ as $\mathrm{KCl}$. The plots were irrigated 10 times during the growing season (each of approximately $500 \mathrm{~m}^{3} \mathrm{ha}^{-1}$ ). Plant height was measured 30 and 60 days (Feekes scale 10) after planting, on 5 randomly chosen plants in the two central rows. The number of leaves on the main stem was counted 60 days after planting. Wheat was harvested February 5, 2001. Roots and shoots were separated and dried at air temperature then weighed.

\section{AM colonization of roots}

In the central rows of each sub-subplot, 3 plants randomly chosen at 45 days after planting, were carefully excavated, and their roots washed free of soil and stained, according to the ink and vinegar technique of Vierheilig et al. (1998), to measure the root length colonization by AM.

\section{Soil and plant analysis}

Soil was air-dried and sieved ( $2 \mathrm{~mm})$, and treated with the Mehlich 3 extractant (Mehlich 1984) for the determination of available elements. Soil organic matter was estimated by the modified Walkley and Black method (McKeague 1978). Plant shoots and roots were air dried and weighed. The spectrophotometric vanado-molybdate method was used to measure P (Tandon et al. 1968). Other minerals were determined in soil extracts by atomic absorption spectrophotometry (Gaines and Mitchell 1979).

\section{Statistical analysis}

A two-factor analysis of variance (P fertilization, TSM) for each parameter was performed using the general linear models procedure of SAS (1990). Means were compared by using the Fisher protected least significance difference (LSD) test (Steel and Torrie 1980).

\section{Results}

Soils S, S1 and S2 from near the phosphate mine in the Tilemsi valley were very low in organic matter, and contained large amounts of available P. The other soil S3, which had grown wheat was collected from Koygour. It was very poor in 
available $\mathrm{P}$, and contained slightly more organic matter (Table 1). When the three cultivars of wheat tested in this work were cultivated in test tubes in the four soils, the rhizoplane and the rhizosphere of plants grown in soil S3 contained total and TSM microbial populations significantly higher than those found in wheat cultivated in the three other soils (Table 2). The highest total population was in the rhizoplane of wheat cultivar Alkama Beri, and the highest TSM population was in the rhizosphere of the cultivar Tetra (Table 2). In the rhizoplane TSM represented from $7 \%$ of the total microbial population as observed with Hindi Tossom to $20 \%$ as observed with Tetra. In the rhizosphere, TSM averaged $10 \%$ of the total microbial populations and the total number of microorganisms expressed as cfu $\mathrm{g}^{-1}$ of dry soil was significantly correlated $(r=0.70, p<0.01)$ to the number of TSM. Such a correlation was not observed in the rhizoplane for which the numbers of microorganisms were expressed as cfu $\mathrm{g}^{-1}$ root dry weight.

Initially we retained 44 bacteria and 18 fungi, isolated from soil or from the rhizoplane or rhizosphere of wheat cultivated in the different soils, because they were able to exhibit an important clarification halo on the TPR-NBRIP medium containing TPR as sole P source. After several subcultures on TPR-NBRIP solid or liquid medium, several isolates lost their capacity to solubilize TPR and were discarded. After 10 subcultures, 6 bacteria and 2 fungi retained their ability to solubilize TPR and were retained for further investigation. The two fungi $\mathrm{C} 1$ and $\mathrm{C} 13$ were isolated from soil $\mathrm{S}$ (Table 1). Bacterial isolates BR2 was obtained from the rhizosphere of the wheat cv. Tetra, and BR8 and BR10 from the rhizosphere of cv. Alkama Beri cultivated in soil S3. Bacteria B3 and $\mathrm{B} 27$ were isolated from soil $\mathrm{S}$ and $\mathrm{B} 22$ from soil $\mathrm{S} 3$. After 10 subcultures the bacterial isolates BR2 and B3 did not show any halo but were able to clarify the culture media underneath the colony growth. These two isolates were retained because they dissolved substantial amount of TPR in liquid media (results not shown). On TPR-NBRIP agar medium, the bacterial clarification halo ranged from 2 to $5 \mathrm{~mm}$ and they were $17 \mathrm{~mm}$ for the fungus $\mathrm{C} 1$ and $12 \mathrm{~mm}$ for $\mathrm{C} 13$.

Table 2. Effect of the wheat cultivars and the four soils used, on the importance of the total (bacteria, actinomycetes and fungi) and TPR-solubilizing microflora (TSM) in the rhizoplane and the rhizosphere of one-month-old wheat plants.

\begin{tabular}{|c|c|c|c|c|c|}
\hline \multirow[t]{2}{*}{ Wheat cultivar } & \multirow[t]{2}{*}{ Soil } & \multicolumn{2}{|c|}{ Rhizoplane $\mathrm{cfu} \times 10^{6} \mathrm{~g}^{-1}$ dry root } & \multicolumn{2}{|c|}{ Rhizosphere $\mathrm{cfu} \times 10^{6} \mathrm{~g}^{-1}$ dry soil } \\
\hline & & Total & TSM & Total & TSM \\
\hline \multirow[t]{4}{*}{ Alkama Beri } & $\mathrm{S}$ & $37.4 \pm 1.5$ & $9.1 \pm 0.3$ & $20.7 \pm 1.6$ & $2.5 \pm 0.4$ \\
\hline & $\mathrm{S} 1$ & $36.1 \pm 1.9$ & $9.5 \pm 0.2$ & $21.7 \pm 1.3$ & $2.8 \pm 0.3$ \\
\hline & $\mathrm{S} 2$ & $30.3 \pm 2.5$ & $8.3 \pm 0.9$ & $19.5 \pm 1.9$ & $2.0 \pm 0.2$ \\
\hline & $\mathrm{S} 3$ & $42.7 \pm 0.8$ & $17.9 \pm 1.7$ & $30.0 \pm 0.3$ & $3.5 \pm 0.3$ \\
\hline \multirow[t]{4}{*}{ Hindi Tossom } & $\mathrm{S}$ & $36.8 \pm 3.6$ & $2.6 \pm 0.4$ & $25.2 \pm 1.2$ & $1.9 \pm 0.2$ \\
\hline & $\mathrm{S} 1$ & $35.7 \pm 2.1$ & $3.0 \pm 0.3$ & $24.8 \pm 2.1$ & $2.3 \pm 0.4$ \\
\hline & $\mathrm{S} 2$ & $23.3 \pm 4.4$ & $1.7 \pm 0.3$ & $19.3 \pm 2.9$ & $1.4 \pm 0.3$ \\
\hline & $\mathrm{S} 3$ & $39.1 \pm 0.6$ & $2.7 \pm 0.6$ & $32.0 \pm 0.7$ & $2.4 \pm 0.4$ \\
\hline \multirow[t]{4}{*}{ Tetra } & $\mathrm{S}$ & $31.1 \pm 2.3$ & $6.0 \pm 0.4$ & $27.5 \pm 1.5$ & $2.6 \pm 0.3$ \\
\hline & $\mathrm{S} 1$ & $32.5 \pm 3.4$ & $6.2 \pm 0.6$ & $28.4 \pm 1.1$ & $3.0 \pm 0.2$ \\
\hline & $\mathrm{S} 2$ & $20.8 \pm 1.7$ & $5.2 \pm 0.4$ & $18.8 \pm 3.0$ & $2.2 \pm 0.3$ \\
\hline & $\mathrm{S} 3$ & $40.7 \pm 1.6$ & $7.6 \pm 0.4$ & $36.2 \pm 0.9$ & $3.4 \pm 0.1$ \\
\hline \multicolumn{6}{|c|}{ Effect of wheat cultivars } \\
\hline Alkama Beri & & $36.6 \mathrm{a}$ & $11.2 \mathrm{a}$ & $23.0 \mathrm{c}$ & $2.7 \mathrm{a}$ \\
\hline Hindi Tossom & & $33.8 \mathrm{~b}$ & $2.5 \mathrm{c}$ & $25.3 \mathrm{~b}$ & $2.0 \mathrm{~b}$ \\
\hline Tetra & & $31.3 \mathrm{c}$ & $6.3 \mathrm{~b}$ & $27.7 \mathrm{a}$ & $2.8 \mathrm{a}$ \\
\hline \multicolumn{6}{|l|}{ Soils effect } \\
\hline & $\mathrm{S}$ & $35.1 \mathrm{~b}$ & $5.9 \mathrm{~b}$ & $24.4 \mathrm{~b}$ & $2.3 \mathrm{c}$ \\
\hline & $\mathrm{S} 1$ & $34.8 \mathrm{~b}$ & $6.2 \mathrm{~b}$ & $25.0 \mathrm{~b}$ & $2.7 \mathrm{~b}$ \\
\hline & $\mathrm{S} 2$ & $24.8 \mathrm{c}$ & $5.1 \mathrm{c}$ & $19.2 \mathrm{c}$ & $1.9 \mathrm{~d}$ \\
\hline & $\mathrm{S} 3$ & $40.8 \mathrm{a}$ & $9.4 \mathrm{a}$ & $32.7 \mathrm{a}$ & $3.1 \mathrm{a}$ \\
\hline
\end{tabular}

Values are mean \pm the standard deviation from 3 replicates; cfu $=$ colony forming units.

Within columns values followed by the same letter are not significantly different $(p<0.05)$ according to the Fisher protected LSD test. 
Table 3. Effect of inoculation of the wheat cv. Tetra with the TPR-solubilizing bacteria (BR2, BR8, Br10, B3, B22 and B27) and fungi $(\mathrm{Cl}$ and $\mathrm{C} 13)$ on seed emergence 5-20 days after sowing.

\begin{tabular}{lllll}
\hline Inoculation treatments & \multicolumn{5}{l}{ Number emerged per 10 seeds } \\
\cline { 2 - 5 } & 5 days & 10 days & 15 days & 20 days \\
\hline Control $^{\mathrm{a}}$ & $3.8 \mathrm{~b}$ & $6.2 \mathrm{~b}$ & $6.5 \mathrm{c}$ & $6.6 \mathrm{c}$ \\
BR2 & $5.2 \mathrm{a}$ & $8.7 \mathrm{a}$ & $8.7 \mathrm{a}$ & $9.0 \mathrm{a}$ \\
BR8 & $1.8 \mathrm{e}$ & $3.5 \mathrm{~d}$ & $4.8 \mathrm{e}$ & $5.2 \mathrm{e}$ \\
BR10 & $3.7 \mathrm{~b}$ & $6.3 \mathrm{~b}$ & $7.0 \mathrm{~b}$ & $8.2 \mathrm{~b}$ \\
B3 & $3.3 \mathrm{c}$ & $6.3 \mathrm{~b}$ & $6.5 \mathrm{c}$ & $8.0 \mathrm{~b}$ \\
B22 & $2.2 \mathrm{~d}$ & $3.5 \mathrm{~d}$ & $3.8 \mathrm{f}$ & $4.0 \mathrm{f}$ \\
B27 & $0.0 \mathrm{f}$ & $1.8 \mathrm{e}$ & $2.8 \mathrm{~g}$ & $3.2 \mathrm{~g}$ \\
C1 & $3.3 \mathrm{c}$ & $5.3 \mathrm{c}$ & $6.2 \mathrm{c}$ & $6.2 \mathrm{~d}$ \\
$\mathrm{C} 13$ & $3.8 \mathrm{~b}$ & $5.3 \mathrm{c}$ & $5.8 \mathrm{~d}$ & $6.2 \mathrm{~d}$ \\
\hline
\end{tabular}

${ }^{\mathrm{a}}$ Inoculated with an autoclaved culture of the bacterial strain BR2.

Values are means of 10 replicates. Within columns values followed by the same letter are not significantly different $(p<0.05)$ according to the Fisher protected LSD test.

Seed inoculation with TSM significantly affected wheat seedling emergence under field conditions (Table 3). On average, emergence increased from $30 \%$ after 5 days to about $52 \%$ after 10 days, $58 \%$ after 15 days and $63 \%$ after 20 days. The bacterial isolate BR2 significantly increased wheat seedlings emergence as compared to the uninoculated control at all dates of measurement. Isolate B27 on the contrary significantly depressed emergence. Five days after sowing there was no seedling emergence when wheat seeds were inoculated with B27, and after 10 days only $18 \%$ of the planted seeds emerged. After 20 days seedling emergence with B27 was about half that of the uninoculated control. Fungi $\mathrm{C} 1$ and $\mathrm{C} 13$ delayed wheat seedling emergence 5 days after sowing, and although the number of seedlings that emerged after 10,15 and 20 days were significantly lower than those observed with the uninoculated control, they were comparable to the averages obtained with all treatments.

P-fertilization treatments of the wheat cv. Tetra significantly affected root colonization by indigenous AM fungi 45 days after planting, plant height after 30 and 60 days of growth, and shoot and root dry matter yields after 60 days growth under field conditions (Table 4). Inoculation of wheat seeds with TSM significantly affected root colonization by AM fungi, plant heights at 30 and 60 days growth and shoot and root dry matter yields (Table 4). The significant interactions between P-fertilization treatments and inoculation with TSM suggest that root colonization with AM fungi, Plant heights after 30 and 60 days of growth and root yields are affected by microbial inoculation in a different manner according to the source of $\mathrm{P}$ used (Table 4). For example AM root colonization of wheat inoculated with bacteria BR10 was significantly higher than that of the uninoculated control in the non fertilized plots and plots fertilized with TPR. However in plots receiving DAP, root colonization with AM was significantly lower than that of the control (Table 5). Plant height was only affected by TSM inoculation after 30 days growth when wheat was fertilized with DAP, and after 60 days when wheat was fertilized with TPR or DAP (Table 5). The highest percentage of AM root colonization was obtained with wheat inoculated with bacteria BR2 in nonfertilized plots as well as in plots fertilized with TPR or DAP (Table 5). Compared to the uninoculated control, BR2 significantly stimulated wheat plant height after 60 days growth when

Table 4. Summary from the analyses of variance for root arbuscular mycorrhizal colonization (\% AM), plant height, leaves number per main stem, shoot and root dry matter yields of wheat cv. Tetra fertilized with TPR or DAP and inoculated with different TPRsolubilizing microorganisms (TSM).

\begin{tabular}{|c|c|c|c|c|c|c|c|}
\hline \multirow[t]{2}{*}{ Source of variations } & \multicolumn{7}{|c|}{ Means squares } \\
\hline & $d f$ & $\% \mathrm{AM}$ & Plant height 30 days & Plant height 60 days & Leaves number & Shoot yield & Root yield \\
\hline Main plots $\mathrm{P}$ & 2 & $381.3 * * *$ & $824.4 * * *$ & $1855.5^{* * *}$ & $1 \mathrm{NS}$ & $3.4^{* * *}$ & $0.2^{* * *}$ \\
\hline Replications & 3 & $1.6 \mathrm{NS}$ & $387.6 * * *$ & $4.1 \mathrm{NS}$ & $16.3^{* * *}$ & $0.8^{*}$ & $0.003 \mathrm{NS}$ \\
\hline Main plots error & 6 & 3.4 & 118.9 & 71.5 & 2.7 & 0.08 & 0.002 \\
\hline Subplots TSM & 8 & $391.7 * * *$ & $16.4^{*}$ & $364.5^{* * *}$ & $1 \mathrm{NS}$ & $0.7 * *$ & $0.03 * * *$ \\
\hline $\mathrm{P} \times \mathrm{TSM}$ & 16 & $131.4 * * *$ & $22.4 * * *$ & $57.5^{*}$ & $0.7 \mathrm{NS}$ & $0.1 \mathrm{NS}$ & $0.01 * * *$ \\
\hline Subplots error & 72 & 2.1 & 6.8 & 31.5 & 0.6 & 0.2 & 0.002 \\
\hline
\end{tabular}

$*, * *, * * *$ Significant at $p<0.05, p<0.01$ and $p<0.001$, respectively. NS $=$ statistically not significant. 


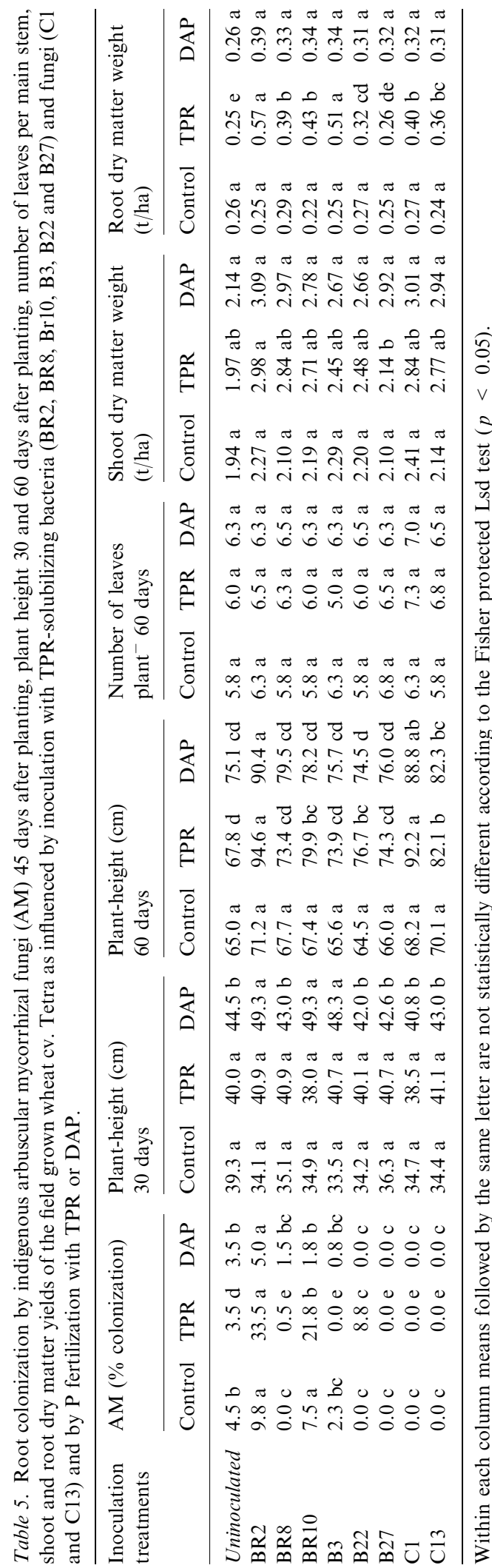

TPR or DAP were added. Comparable results were obtained when wheat was inoculated with the two fungal isolates $\mathrm{C} 1$ and $\mathrm{C} 13$. The number of leaves per main stem was not affected by P-fertilization treatments or by seed inoculation treatments (Table 5).

After 60 days of growth, the shoot dry matter yields of the cv. Tetra of wheat was not influenced by inoculation with TSM in the non- or DAP fertilized plots (Table 5). When wheat was cultivated with TPR, all inoculation treatments produced similar shoot dry matter yields, however the yield obtained with BR2 was significantly higher than that of B27. All TSM inoculation treatments, except with bacteria B27, significantly stimulated root dry matter yield (Table 5). The observed increases in root dry matter yields ranged from $28 \%$ with bacteria B22 to $128 \%$ with BR2 and from $44 \%$ with the fungus $\mathrm{C} 13$ to $60 \%$ with $\mathrm{C} 1$.

In general in the presence of DAP, wheat root length colonized with indigenous AM fungi was always lower than observed in TPR amended or in the unfertilized control plots (Tables 5 and 6). For all inoculation treatments combined, P-fertilization with TPR or DAP significantly enhanced plant height after 30 or 60 days growth (Table 6). The tallest plants were observed in plots fertilized with DAP after 30 days growth, however after 60 days no significant difference was observed between plant fertilized with TPR or DAP (Table 6). Fertilization with $30 \mathrm{~kg} \mathrm{ha}^{-1}$ of $\mathrm{P}$ significantly stimulated shoot dry matter yield of 60day-old wheat cv. Tetra, but DAP was a better source than TPR (Table 6). P-fertilization also

Table 6. Effect of fertilization with $30 \mathrm{~kg} \mathrm{P} \mathrm{ha}^{-1}$ applied as TPR or DAP on wheat cv. Tetra height 30 and 60 days after planting, number of leaves per main stem, shoot and root dry matter yields.

\begin{tabular}{lccc}
\hline Variables & Control & TPR & DAP \\
\hline AM \% colonization & $2.6 \mathrm{~b}$ & $7.6 \mathrm{a}$ & $1.4 \mathrm{c}$ \\
Plant height 30 days $(\mathrm{cm})$ & $37.2 \mathrm{c}$ & $40.2 \mathrm{~b}$ & $44.7 \mathrm{a}$ \\
Plant height 60 days $(\mathrm{cm})$ & $67.3 \mathrm{~b}$ & $79.4 \mathrm{a}$ & $80.0 \mathrm{a}$ \\
Shoot number & $6.03 \mathrm{a}$ & $6.25 \mathrm{a}$ & $6.4 \mathrm{a}$ \\
Shoot yield $(\mathrm{t} / \mathrm{ha})$ & $2.19 \mathrm{c}$ & $2.59 \mathrm{~b}$ & $2.80 \mathrm{a}$ \\
Root yield $(\mathrm{t} / \mathrm{ha})$ & $0.26 \mathrm{c}$ & $0.39 \mathrm{a}$ & $0.33 \mathrm{~b}$
\end{tabular}

Values are means of all inoculation treatments (TPR-solubilizing microorganisms).

In each line means followed by the same letter are not statistically different according to the Fisher protected Lsd test $(p<0.05)$. 
stimulated root dry matter yield, however in that case TPR was a better P source than DAP.

None of the bacteria or fungi tested produced $\mathrm{HCN}$ or exhibited any antagonistic activity towards all other selected TSM. Bacteria BR2, BR10 and $\mathrm{B} 3$ produced siderophores and BR2, BR10, B3 and $\mathrm{B} 22$ produced indoleacetic acid or related compounds. The two fungi $\mathrm{C} 1$ and $\mathrm{C} 13$ did not produce siderophores or indoleacetic acid.

\section{Discussion}

In this work, we used two different methods to isolate TSM from the four soils collected in Mali. The first was based on the methodology developed by Scher et al. (1984) and was aimed at isolating rhizosphere competent TSM. The second method used for comparison purpose was by bulk soil enrichment. At the end of the screening procedures the effective TSM obtained from the rhizosphere of wheat were only bacteria (BR2, BR8 and BR10). Bulk soil enrichment in addition to three more TPR solubilizing bacteria (B3, B27 and B22) allowed the isolation of the two fungi $\mathrm{C} 1$ and $\mathrm{C} 13$. Bacteria are the most numerous inhabitants of the rhizosphere (Kennedy 1999) and thus direct isolation from the rhizosphere probably favored the growth of bacteria on TPR-NBRIP agar plates and reduced the chances of isolating effective phosphate solubilizing fungi. In fact, a rhizosphere competent inorganic P-solubilizing fungal isolate of Penicillium rugulosum, was previously isolated directly from soil (Reyes et al. 2002). As fungi produce spores, which are more resistant to adverse environmental conditions like drought or high temperature, screening for phosphate solubilizing microorganisms to be used in area subjected to such stresses should also include isolation from bulk soil.

To screen for TSM with high activity we used the improved NBRIP-medium described by Nautiyal (1999) supplemented with TPR as sole P source. All selected microorganisms were tested for TPR solubilization on agar plates as well as in liquid medium to avoid the discrepancy observed between the two methods. Many observations indicate that some phosphate solubilizing microorganisms lose this trait after several subcultures on agar plate (Rodriguez and Fraga 1999). The 6 bacteria and the 2 fungi selected here were subjected to 10 streaking on TPR-NBRIP agar plates. The two bacterial isolates BR2 and B3 did lose the ability to produce a halo larger than the colony diameter, however they were retained because they were able to solubilize large amount of TPR in the liquid medium.

When the three wheat cultivars were grown in test tubes in the four different soils used in this study, about $8-12 \%$ of the total microbial population were TSM (Table 2). This contrast with the higher percentages $(26-46 \%)$ of calcium phosphate solubilizing microorganisms previously observed in some Canadian soils (Chabot et al. 1993), and it confirms that microorganisms mobilize $\mathrm{P}$ better from insoluble inorganic phosphate salts than from naturally occurring phosphate rocks (Rodriguez and Fraga 1999).

A significant correlation $(r=0.69, p<0.01)$ was observed between the total microbial populations numbers in the rhizosphere (expressed as cfu $\mathrm{g}^{-1}$ of dry soil) and in the rhizoplane (expressed as cfu $\mathrm{g}^{-1}$ of dry roots) of the three wheat cultivars. Although the total number of microorganisms was significantly correlated to the number of TSM $(r=0.70, p<0.01)$ in the rhizosphere, no such correlation was observed in the rhizoplane. The laboratory techniques presently used to estimate the numbers of phosphate-solubilizing microorganisms (PSM) in plant roots are not accurate. In fact, the presence of a high number of PSM in the rhizosphere does not necessarily translate into a higher plant $\mathrm{P}$ uptake or a higher $\mathrm{P}$ concentration in shoots (Reyes et al. 2002). This can be attributed in part to the fact that organisms identified as PSM on agar plates do not necessarily have this trait in vivo in the rhizosphere or the rhizoplane. Gyaneshwar et al. (2002) suggested the use of buffered culture media when screening for PSM to reflect the buffering capacity of soils, and this should be tested in future large screening studies. However because of the complexity of the interactions taking place in the rhizosphere between plants, soils, microorganisms and other constituents of soil fauna (see for example: Knox et al. 2003), and as PSM can also influence plant growth by several other different mechanisms of action (Chabot et al. 1996), more global investigations are required to understand better how PSM act within a complex soil biota and why some PSM can stimulate plant growth without enhancing $P$ uptake (De Freitas et al. 1997). 
When the cv. Norstar of winter wheat was inoculated with plant growth promoting rhizobacteria (PGPR), and grown in soil in pot experiments, some isolates induced significant increases in seedling emergence rates (De Freitas and Germida 1990). In this work, inoculation of the wheat cv. Tetra with the bacterial isolate BR2 significantly enhanced seedling emergence very early (5 days) after planting. Enhancement of seedling emergence can be the result of the antagonistic activity of the introduced bacterium against some plant pathogens (De Freitas and Germida 1990), or the production of phytohormones. The four bacteria BR2, BR10, B3 and B22 produced indoleacetic acid, and three isolates BR2, BR10 and B3 produced siderophores which can specifically inhibit or reduce the growth of some fungal pathogens, however only BR2 showed the highest and the most sustained enhancement rates. This is probably linked to the ability of isolate BR2 to stimulate significantly the beneficial natural symbiosis between wheat and indigenous AM fungi. In fact regardless of the fertilization treatment applied, BR2 significantly stimulated wheat root colonization with indigenous AM fungi, and thus it can be considered as a mycorrhizal helper bacterium (Barea et al. 2002). Wheat mycorrhizal plants are more water-use efficient than nonmycorrhizal plants (Al-Karaki 1998), and mycorrhizal plants have many mechanisms that reduce the damage caused by soil-borne pathogens (Barea et al. 2002). The two fungal isolates $C 1$ and $C 13$ and the bacterial isolate $\mathrm{B} 27$ inhibited colonization by indigenous mycorrhizas 45 days after planting. These three TSM also delayed seedling emergence. However as compared to the uninoculated control, these negative observations did not influence any of the wheat growth parameters measured in this study (plant height after 30 and 60 days, shoot and root dry matter yields after 60 days). These results are comparable to those obtained by Germida and Walley (1996) during their evaluation of the effect of inoculation of spring wheat with PGPR under field conditions. They measured significant transient increases or decreases in plant shoot and root biomass and AM root colonization at different intervals but the final seed yield was not affected significantly.

Soil fertilization with $30 \mathrm{~kg} \mathrm{ha}^{-1} \mathrm{P}$ added as TPR or DAP significantly enhanced all the parameters measured. DAP significantly stimulated plant height 30 days after planting and shoot dry matter yields harvested 60 days after planting, and TPR stimulated root dry matter yield at harvest. With TPR root colonization with indigenous AM fungi was approximately five times more important than with DAP. This corroborates the results of Barea et al. (1980) showing that phosphate rock does not reduce the level of root infection with AM as compared to the addition of soluble P. The observed percentages of wheat root colonization by natural AM fungi present in the Koygour soil are very low. Many adverse soil conditions like elevated temperature and water stress (Entry et al. 2002) can explain this, and wheat will probably benefit from inoculation with an appropriate isolate of AM (Graham and Abbott 2000).

In Mali, soils are frequently exposed to elevated temperature and drought; therefore the use of TSM producing resistant spores will be preferable for the success of inoculation under these difficult conditions. Endospore-forming bacteria belonging to the genus Bacillus include PSM isolates (De Freitas et al. 1997), which will adapt to such harsh conditions. The TSM selected in this study were identified by the laboratory of Dr Carole Beaulieu at the University of Sherbrooke (Quebec, Canada) by using the Biolog systems and the sequencing of the 16S rDNA, and none of the isolated bacteria belonged to the bacilli. For this reason and because of their high TPR solubilizing activities, the two fungi $\mathrm{C} 1$ and $\mathrm{C} 13$ were retained for future investigations. Isolate $\mathrm{C} 1$ was identified as Aspergillus awamori Nakazawa, and $\mathrm{C} 13$ as Penicillium chrysogenum Thom. The bacterial isolate BR2 identified as a Pseudomonas sp. was also retained because it is an important mycorrhizal helper bacterium and has superior plant growth promoting activities with wheat fertilized with TPR. The two fungal isolates $\mathrm{C} 1$ and $\mathrm{C} 13$, the bacterial isolate BR2 and a commercial AM isolate of Glomus intraradices were used to inoculate the cv. Tetra of wheat in field plots established in Koygour during the 2001-2002 growing season (Babana and Antoun 2005). Bacteria BR2 confirmed its mycorrhizal helper trait and inoculation of wheat with $G$. intraradices significantly increased wheat grain yield and $\mathrm{P}$ content. The highest grain yield and $\mathrm{P}$ content was obtained with TPR fertilized wheat inoculated with BR2, C1 and G. intraradices (Babana and Antoun 2005). More field inoculation trials should be performed in 
many different regions in Mali and other parts of Africa, and with other wheat cultivars, before a commercial inoculant formulation based on these beneficial TSM can be developed.

\section{Acknowlegments}

Babana, A.H. was the recipient of a doctoral fellowship from Le Program de bourses d'excellence de la Francophonie (PCBF). The authors are grateful to the following persons in Mali who helped in the logistics and the establishment of the field plots: A. Allaye and the farmers of Koygour (Diré); Oumar Bonkano Traoré, Bakara Diallo and the personnel of PACCEM Diré, the director of the IER and Anne-Marie Marcotte. Many thanks to Professor M.P. Cescas, for his continuous encouragement and support, for his valuable advices and constructive comments.

\section{References}

Al-Karaki G.N. 1998. Benefit, cost and water-use efficiency of arbuscular mycorrhizal durum wheat grown under drought stress. Mycorrhiza 8: 41-45.

Babana A.H. and Antoun H. 2005. Effect of Tilemsi phosphate rock-solubilizing microorganisms on phosphorus uptake and yield of field-grown wheat (Triticum aestivum L.) in Mali. Plant Soil: in press.

Bakker A.W. and Schippers B. 1987. Microbial cyanide production in the rhizosphere in relation to potato yield reduction and Pseudomonas spp.-mediated plant growthstimulation. Soil Biol. Biochem. 19: 451-457.

Barea J.M., Escudero J.L. and Azcón-Aguilar C. 1980. Effects of introduced and indigenous VA mycorrhizal fungi on nodulation, growth and nutrition of Medicago sativa in phosphate-fixing soils as affected by P-fertilizers. Plant Soil 54: 283-296.

Barea J.M., Azcon R. and Azcon-Aguilar C. 2002. Mycorrhizosphere interactions to improve plant fitness and soil quality. Antonie van Leeuwenhoek 81: 343-351.

Bationo A., Ayuk E., Ballo D. and Koné M. 1997. Agronomic and economic evaluation of Tilemsi phosphate rock in different agroecological zones of Mali. Nutrient cycling Agrosyst. 48: 179-189.

Bolland M.D.A. and Gilkes R.J. 1997. The agronomic effectiveness of reactive phosphate rocks. 2. Effect of phosphate rock reactivity. Aust. J. Exp. Agric. 37: 937-946.

Bric J.M., Bostock R.M. and Silverstone S.E. 1991. Rapid in situ assay for indoleacetic acid production by bacteria immobilized on nitrocellulose membrane. Appl. Environ. Microbiol. 57: 535-538.
Chabot R., Antoun H. and Cescas M.P. 1993. Stimulation de la croissance du maïs et de la laitue romaine par des microorganismes dissolvant le phosphore inorganique. Can. J. Microbiol. 39: 941-947.

Chabot R., Antoun H. and Cescas M.P. 1996. Growth promotion of maize and lettuce by phosphate-solubilizing Rhizobium leguminosarum biovar phaseoli. Plant Soil 184: 311-321.

De Freitas J.R. and Germida J.J. 1990. Plant growth promoting rhizobacteria for winter wheat. Can. J. Microbiol. 36: 264-272.

De Freitas J.R., Banerjee M.R. and Germida J.J. 1997. Phosphate-solubilizing rhizobacteria enhance the growth and yield but not phosphorus uptake of canola (Brassica napus L.). Biol. Fertil. Soils. 24: 358-364.

Entry J.A., Rygiewicz P.T., Watrud L.S. and Donnelly P.K. 2002. Influence of adverse soil conditions on the formation and function of arbuscular mycorrhizas. Adv. Environ. Res. 7: $123-138$.

Gagné S., Antoun H. and Richard C. 1985. Inhibition des champignons phytopathogènes par des bactéries isolées du sol et de la rhizosphère de légumineuses. Can. J. Microbiol. 31: 856-860.

Gaines P.T. and Mitchell A.G. 1979. Chemical methods for Soil and Plant Analysis. University of Georgia, Coastal Plain Station, Tifton, USA, $105 \mathrm{pp}$.

Germida J.J. and Walley F.L. 1996. Plant growth-promoting rhizobacteria alter rooting patterns and arbuscular mycorrhizal fungi colonization of field-grown spring wheat. Biol. Fert. Soils 23: 113-120.

Goldstein A.H. 1986. Bacterial solubilization of mineral phosphate: historical perspective and future prospects. Am. J. Altern. Agric. 1: 51-57.

Graham J.H. and Abbott L.K. 2000. Wheat responses to aggressive and non-aggressive arbuscular mycorrhizal fungi. Plant Soil 220: 207-218.

Gyaneshwar P., Naresh Kumar G.L., Parekh J. and Poole P.S. 2002. Role of soil microorganisms in improving $P$ nutrition of plants. Plant Soil 245: 83-93.

Kennedy A.C. 1999. The Rhizosphere and the spermosphere. In: Sylvia D.M., Fuhrmann J.J., Hartel P.G. and Zuberer D.A. (eds), Principles and Applications of Soil Microbiology. Prentice Hall, Toronto, pp. 389-407.

Knox O.G.G., Killham K., Mullins C.E. and Wilson M.J. 2003. Nematode-enhanced microbial colonization of the wheat rhizosphere. FEMS Microbiol. Let. 225: 227-233.

Large E.C. 1954. Growth stages in cereals: illustration of the Feekes scale. Plant Pathol. 3: 128-129.

McKeague J.A. (ed.), 1978. Manual of Soil Sampling and Methods of Analysis. Canadian Soil Survey Committee Canadian Society of Soil Science, Ottawa, 223 pp.

Mehlich A. 1984. Mehlich 3 soil test extractant: a modification of Mehlich 2 extractant. Commun. Soil Sci. Plant Anal. 15: 1409-1416.

Milagres A.M.F., Machuca A. and Napoleao D. 1999. Detection of siderophore production from several fungi and bacteria by a modification of chrome azurol S (CAS) agar plate assay. J. Microbiol. Methods 37: 1-6.

Nautiyal C.S. 1999. An efficient microbiological growth medium for screening phosphate solubilizing microorganisms. FEMS Microbiol. Lett. 170: 265-270. 
Reyes, I, Bernier L. and Antoun H. 2002. Rock phosphate solubilization and colonization of maize rhizosphere by wild and genetically modified strains of Penicillium rugulosum. Microb. Ecol. 44: 39-48.

Richardson A.E. 2001. Prospects for using soil microorganisms to improve the acquisition of phosphorus by plants. Aust. J. Plant Physiol. 28: 897-906.

Rodriguez H. and Fraga R. 1999. Phosphate solubilizing bacteria and their role in plant growth promotion. Biotechnol. Adv. 17: 319-339.

SAS, Institute Inc 1990. SAS procedure guide version 6 edition. SAS Institute Inc, Car, NC, 705 pp.
Scher F.M., Zieglle J.S. and Klopper J.W. 1984. A method for assessing the root-colonizing capacity of bacteria on maize. Can. J. Microbiol. 30: 151-157.

Steel R.G.D. and Torrie J.H. 1980. Principles and procedures of statistics, a biometrical approach. MacGraw-Hill Book Co, New York.

Tandon H.L.S., Cescas M.P. and Tyner E.H. 1968. An acid-free vanadate-molybdate reagent for the determination of total phosphorus in soils. Soil Sci. Soc. Am. Proc. 32: 48-51.

Vierheilig H., Goughlan A.P., Wyss U. and Piché Y. 1998. Ink and vinegar, a simple technique for arbuscular-mycorrhizal fungi. Appl. Environ. Microbiol. 64: 5004-5007. 